\title{
PENGEMBANGAN MEDIA AJAR LUBANG HITAM MENGGUNAKAN MODEL PENGEMBANGAN ADDIE
}

\author{
Hasrian Rudi Setiawan*, Arwin Juli Rakhmadi, Abu Yazid Raisal
}

\author{
Program Studi Pendidikan Agama Islam \\ Fakultas Agama Islam Universitas Muhammadiyah Sumatera Utara \\ Jl. Kapten Mukhtar Basri No. 3 Medan, 20238 Sumatera Utara \\ e-mail*: hasrianrudi@umsu.ac.id
}

\begin{tabular}{|l|l|l|l} 
Diterima 10 Juni 2021 & Direvisi 2 September 2021 & Disetujui 4 September 2021 & Dipublikasikan 11 September 2021
\end{tabular}

https://doi.org/10.33369/jkf.4.2.112-119

\begin{abstract}
ABSTRAK
Penelitian ini bertujuan untuk mengembangkan sebuah media ajar tentang lubang hitam di Observatorium Ilmu Falak Universitas Muhammadiyah Sumatera Utara (OIF UMSU). Jenis penelitian ini adalah Research and Development (penelitian dan pengembangan). Model pengembangan yang digunakan adalah model pengembangan ADDIE (Analysis, Design, Development, Implemetation, dan Evaluation). Penelitian ini dibatasi hanya sampai tahap Development. Berdasarkan penilaian dari dua validator untuk media, rata-rata nilai yang diperoleh adalah 76,88\%. Dari segi media, media ajar lubang hitam ini masuk kategori cukup layak untuk dikembangkan. Berdasarkan penilaian dari dua validator untuk materi, rata-rata nilai yang diperoleh adalah $80,36 \%$. Dari segi media, media ajar lubang hitam ini masuk kategori layak untuk dikembangkan. Rata-rata validasi dari ahli media dan ahli materi adalah 78,62\% dengan kategori cukup layak.
\end{abstract}

Kata kunci: media ajar, lubang hitam, ADDIE

\begin{abstract}
This study aims to develop a teaching media about black holes at Observatorium Ilmu Falak Universitas Muhammadiyah Sumatera Utara (OIF UMSU). This type of research is Research and Development (research and development). The development model used is the ADDIE development model (Analysis, Design, Development, Implementation, and Evaluation). This research was limited only to the Development stage. Based on the assessments of the two validators for the media, the average value obtained is $76.88 \%$. In terms of media, the black hole teaching media is categorized as quite feasible to be developed. Based on the assessments of the two validators for the material, the average value obtained is $80.36 \%$. In terms of media, the black hole teaching media is categorized as feasible to be developed. The average validation from media and material experts was $78.62 \%$ with a decent enough category.
\end{abstract}

Keywords: teaching media, black hole, ADDIE

\section{PENDAHULUAN}

Lubang hitam merupakan suatu daerah dalam ruang-waktu dengan medan gravitasi begitu kuat bahkan cahaya tidak dapat lolos (1). Lubang hitam terbentuk ketika sebuah bintang masif mengalami keruntuhan. Radius kritis dimana sebuah bintang menjadi lubang hitam dikenal dengan radius Schwarzschild (2). Lubang hitam tidak dapat diamati secara langsung dikarenakan cahaya tidak dapat lolos dari lubang hitam. Lubang hitam diamati melalui interaksi terhadap bintang di sekitarnya. Ilmuwan mengamati cahaya tersebut untuk memahami lubang hitam (3). Lubang hitam memiliki singularitas dengan kerapatan dan kelengkungan ruang waktu yang tidak terhingga (4). Lubang hitam sudah banyak dikenal dalam ilmu fisika dan astronomi, namun masih banyak masyarakat yang belum mengetahui apa itu lubang hitam. Ketersediaan buku pengetahuan tentang lubang hitam masih sedikit dan kebanyakan masih tergabung dalam ensiklopedia astronomi dan pembahasannya tidak terlalu dalam (5). Di dalam kurikulum sekolah di Indonesia, astronomi dan IPA (fisika) meruapakan materi pelajaran yang terpadu secara integral, di mana konsep astronomi melibatkan konsep fisika (6). Pembelajaran IPA tidak terbatas pada belajar fakta, konsep, prinsip, 
hukum, tetapi juga belajar tentang cara memperoleh informasi, penerapan tekonologi, bekerja secara ilmiah, dan kemampuan berpikir (7).

Pembelajaran adalah suatu proses, yakni proses mengatur, mengorganisasi lingkungan yang ada di sekitar sehingga dapat menumbuhkan dan mendorong seseorang dalam melakukan proses belajar (8). Salah satu faktor yang dapat menyebabkan kesulitan dalam proses pembelajaran adalah pendidik tidak menggunakan alat peraga (9). Media pembelajaran adalah alat yang dapat membantu proses kegiatan belajar mengajar sehingga makna pesan dari pembelajaran yang disampaikan menjadi lebih jelas dan tujuan pembelajaran dapat tercapai dengan efektif dan efisien (10). Dengan menggunakan media pembelajaran yang tepat, pendidik merangsang minat pembelajar mengenai materi yang disajikan (11). Penggunaan media dalam proses pembelajaran memiliki beberapa manfaat seperti, memberikan suasana yang menyenangkan dalam belajar, memberikan variasi dalam pembelajaran, menghadirkan obyek-obyek yang sukar didapat ke dalam lingkungan belajar, mengatasi keterbatasan ruang, waktu dan daya indera, dan membuat nyata konsep yang abstrak (12).

Media ajar yang dikembangkan akan diperuntukkan bagi pengunjung di Observatorium Ilmu Falak Universitas Muhammadiyah Sumatera Utara (OIF UMSU). Observatorium merupakan sebuah bangunan yang digunakan untuk melakukan pengamatan tercatat terhadap benda-benda langit (13). Observatorium Ilmu Falak Universitas Muhammadiyah Sumatera Utara (OIF UMSU) merupakan sebuah lembaga di Universitas Muhammadiyah Sumatera Utara (UMSU) yang bergerak di bidang ilmu falak (astronomi) Yang bertujuan untuk mengembangkan dan mengenalkan dan ilmu falak (astronomi) kepada masyarakat (14). OIF UMSU memiliki instrumen astronomi mulai dari instrumen klasik hingga instrumen modern (15). Namun saat ini tidak ada instrumen yang dapat digunakan untuk mengajarkan lubang hitam.

Mengenalkan lubang hitam kepada masyarakat bukanlah hal yang mudah karena lubang hitam merupakan sesuatu yang abstrak. Dibutuhkan sebuah media pembelajaran agar lubang hitam dapat diajarkan dengan lebih mudah. Salah satu media yang telah dibuat guna memudahkan dalam memahami lubang hitam adalah buku pengayaan mengenai kajian fisis lubang hitam untuk tingkat SMA (5). Namun saat ini belum ada media yang berupa alat peraga yang yang terkait dengan lubang hitam. Penelitian ini bertujuan untuk mengembangkan sebuah media ajar tentang lubang hitam yang akan digunakan oleh pengunjung Observatorium Ilmu Falak Universitas Muhammadiyah Sumatera Utara (OIF UMSU) dan mengetahui kelayakannya.

\section{METODE PENELITIAN}

Jenis penelitian ini adalah Research and Development (penelitian dan pengembangan) yang merupakan suatu proses untuk mengembangkan suatu produk baru atau menyempurnakan produk yang sudah ada, yang dapat dipertanggungjawabkan. Model pengembangan yang digunakan adalah model pengembangan ADDIE, yaitu model pengembangan yang terdiri dari lima tahapan yaitu, Analysis (analisis), Design (desain), Development (pengembangan), Implemetation (implementasi), dan Evaluation (evaluasi) (16). Penelitian pengembangan model ADDIE yang dilakukan hanya sampai tahap Development (Pengembangan), karena tujuan penelitian ini hanya sebatas mengembangkan dan menghasilkan suatu media pembelajaran yang valid untuk diimplementasikan berdasarkan penilaian validator seperti terlihat pada gambar 1 . 


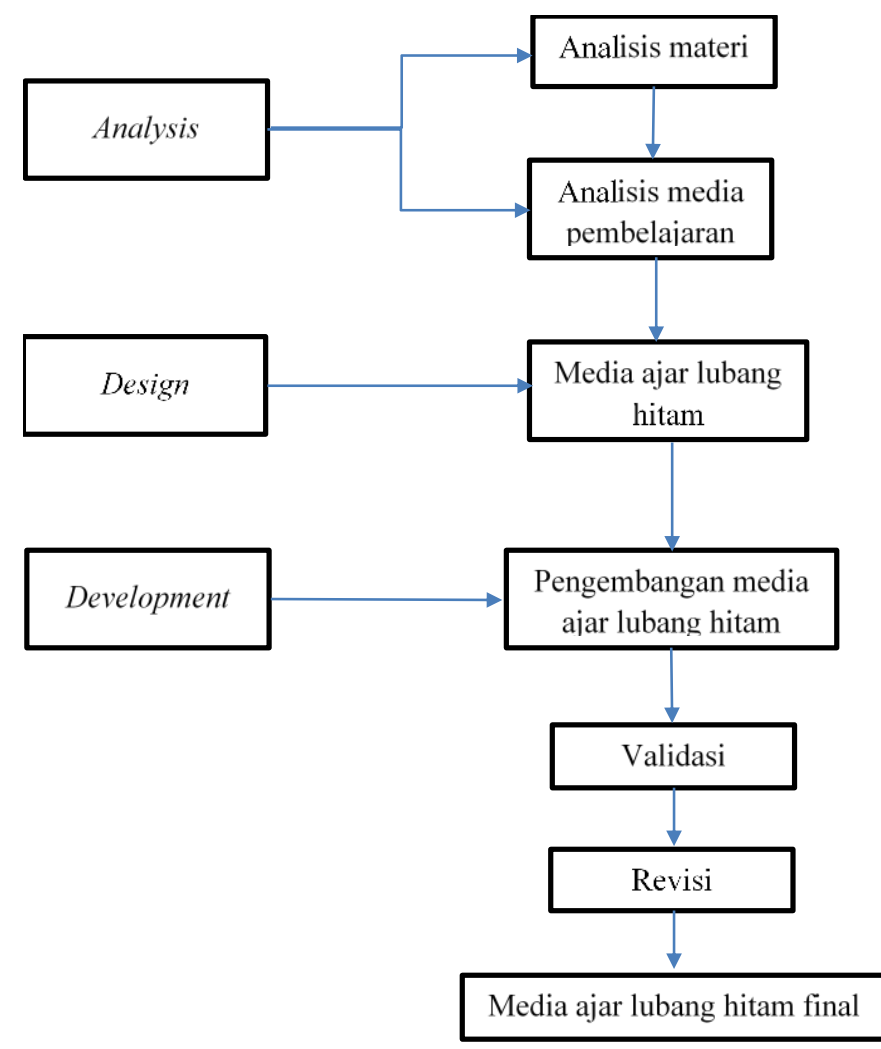

Gambar 1. Model pengembangan ADDIE

Tahap-tahap penelitian pengembangan tersebut dijelaskan seperti dibawah ini:

a. Analysis (Analisis), tahap analisis terhadap pengembangan produk yang dilakukan terdiri dari analisis materi dan analis media pembelajaran. Dari analisis tersebut diperleh bahwa ketersedian media yang membahas mengenai lubang hitam sangat sedikit dan tidak mendalam. Dengan adanya media ajar lubang hitam pendidik dapat memberikan penjelasn secara konkrit dari materi yang bersifat abstrak tersebut.

b. Design (Desain), pada tahap desain yang dilakukan antara lain yaitu: 1) mendesain media ajar lubang hitam; 2) Lembar validasi ahli media dan ahli materi. Validasi instrumen yang digunakan berupa angket yang diberikan kepada ahli materi dan ahli media. Desain media ajar lubang hitam dapat dilihat pada gambar 2 .
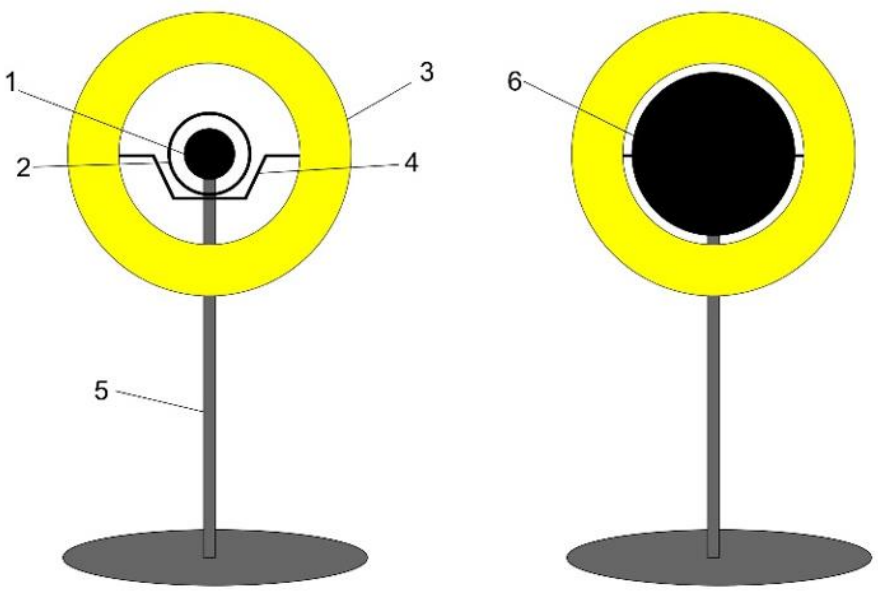

Gambar 2. Desain media ajar lubang hitam

Keterangan gambar:

1. Bagian 1 merupakan sebuah bola hitam yang merepresentasikan horizon peristiwa pada lubang hitam 
2. Bagian 2 merupakan kawat yang berbentuk lingkaran yang merepresentasikan jarak aman benda-benda masih dapat mengorbit lubang hitam dalam orbit berbentuk lingkaran dengan jari-jari sebesar 1.5 kali radius Schwarzschild.

3. Bagian 3 merupakan kertas yang berbentuk lingkaran yang merepresentasikan piringan akresi yang mengelilingi sebuah lubang hitam.

4. Bagian 4 terbuat dari kawat yang berfungsi sebagai penyangga piringan akresi (bagian 3). Bagian ini melekat dengan bagian 5 .

5. Bagian 5 merupakan tiang besi yang berfungsi untuk menempatkan bagian-bagian lainnya dan sebagai penyangga agar media bisa berdiri tegak.

6. Bagian 6 kawat berbentuk lingkaran yang dilapisi dengan kertas berwarna hitam yang merepresentasikan horizon peristiwa yang dilihat oleh pengamat. Bagian ini menggambarkan seluruh permukaan horizon peristiwa yang berbentuk bola.

c. Development (Pengembangan), hasil dari tahap pengembangan yaitu: 1) media ajar lubang hitam; 2) buku panduan penggunaan; 3) Skor validasi materi dan media.

Uji validitas media ajar lubang hitam dilakukan oleh validator ahli media dan validator ahli materi. Selanjutnya validator diminta untuk memberikan penilaian secara umum dan saran terhadap media yang dikembangkan. Teknik analisis data yang digunakan pada penelitian ini adalah analisis deskriptif, yakni dengan menghitung persentase nilai hasil validasi seperti pada persamaan 1 .

$$
\text { persentase }=\frac{\text { skor yang diperoleh }}{\text { skor maksimal }} \times 100 \%
$$

Tingkat kelayakan produk hasil penelitian pengembangan diidentikkan dengan presentasi skor. Semakin besar skor yang diperoleh maka produk hasil pengembangan semakin baik tingkat kelayakannya. Kriteria dalam pengambilan keputusan dalam validasi media dapat dilihat pada tabel 1 .

Tabel 1. Kriteria kelayakan media pembelajaran

\begin{tabular}{ccc}
\hline No & Persentase & Keterangan \\
\hline 1 & $80 \%-100 \%$ & Layak \\
2 & $60 \%-79,99 \%$ & Cukup Layak \\
3 & $50 \%-59,99 \%$ & Kurang Layak \\
4 & $0-49,99 \%$ & Tidak Layak (diganti) \\
\hline
\end{tabular}

\section{HASIL DAN PEMBAHASAN}

\subsection{Hasil}

Produk yang dihasilkan dari penelitian ini berupa media ajar lubang hitam dan buku panduan. Media ini dibuat dan dirancang dengan tujuan menjadi instrumen yang dapat digunakan untuk mengajarkan tentang lubang hitam dengan cara yang mudah di OIF UMSU. Pengembangan media pembelajaran ini menggunakan model perancangan media pembelajaran model ADDIE. Model ADDIE memiliki 5 tahapan antara lain Analysis (Analisis), Design (Desain), Development (Pengembangan), Implementation (Implementasi) dan Evaluation (Evaluasi). Penelitian pengembangan model ADDIE yang dilakukan hanya sampai tahap Development (Pengembangan), karena tujuan penelitian ini hanya sebatas mengembangkan dan menghasilkan suatu media pembelajaran yang valid untuk diimplementasikan berdasarkan penilaian validator.

Validator untuk media terdiri dari dua orang ahli yang bekerja sebagai dosen di bidang pendidikan. Berdasarkan hasil analisis validasi ahli media mengenai media ajar yang dikembangkan menghasilkan persentase sebesar 76,88 \% seperti terlihat pada tabel 2. Aspek yang dinilai meliputi tampilan fisik, gambar, warna, tulisan, dan pemakaian. Aspek fisik terdiri dari keamanan, keawetan, kesesuain dan kemenarikan media. Aspek gambar terdiri dari kejelasan dan kesesuaian media. Aspek warna terdiri dari kesesuaian warna dan kesesuaian pola. Aspek tulisan terdiri dari 
kesesuaian ukuran, font, dan warna tulisan. Aspek pemakaian terdiri dari kesesuaian media terhadap pengguna, kepraktisan, dan ketepatan media.

Tabel 2. Hasil validasi ahli media

\begin{tabular}{lcrrr}
\hline \multicolumn{1}{c}{ Aspek } & Ahli I & Ahli II & Rata-rata & Total \\
\hline Fisik & $81.25 \%$ & $75.00 \%$ & $78.13 \%$ & \\
Gambar & $87.50 \%$ & $62.50 \%$ & $75.00 \%$ & \\
Warna & $75.00 \%$ & $87.50 \%$ & $81.25 \%$ & $76.88 \%$ \\
Tulisan & $75.00 \%$ & $75.00 \%$ & $75.00 \%$ & \\
Pemakaian & $66.67 \%$ & $83.33 \%$ & $75.00 \%$ & \\
\hline
\end{tabular}

Terdapat beberapa saran dari ahli media yang dapat digunakan untuk memperbaiki media yang telah dihasilkan. Berikut beberapa saran dari ahli media:

a. Media pembelajaran ini sudah sangat bagus pengembangannya, akan tetapi perlu perbaikan terkait kesesuaian pengguna yang memiliki variasi usia.

b. Bahan yang digunakan bisa lebih ringan sehingga dapat lebih menarik jika diproduksi.

Validator untuk materi terdiri dari dua orang ahli yang bekerja sebagai dosen di bidang pendidikan. Berdasarkan hasil analisis validasi ahli materi mengenai media ajar dikembangkan menghasilkan persentase sebesar $80,36 \%$ seperti terlihat pada tabel 3 . Aspek yang dinilai meliputi kesesuaian materi dan media. Aspek kesesuaian materi terdiri dari kesesuaian materi, kejelasan materi, kemenarikan materi, kebenaran materi, kesesuaian materi terhadap pengguna, dan kejelasan Bahasa. Aspek media terdiri dari kemudahan penggunaan media, kesesuaian media dengan materi, dan media menumbuhkan minat belajar.

Tabel 3. Hasil validasi ahli materi

\begin{tabular}{lcccc}
\hline \multicolumn{1}{c}{ Aspek } & Ahli I & Ahli II & Rata-rata & Total \\
\hline Kesesuaian Materi & $71.43 \%$ & $75.00 \%$ & $73.21 \%$ & \multirow{2}{*}{$80.36 \%$} \\
Media & $75.00 \%$ & $100.00 \%$ & $87.50 \%$ & \\
\hline
\end{tabular}

Terdapat beberapa saran dari ahli materi yang dapat digunakan untuk memperbaiki media yang telah dihasilkan. Berikut beberapa saran dari ahli materi:

a. Sebaiknya media pembelajaran disesuaikan dengan kurikulum yang ada di pelajaran sekolah maupun universitas agar sinkron dan bermanfaat.

b. Metode penyampaian dan pengajaran lebih diperluas.

c. Media pembelajaran yang dikembangkan sudah sangat baik, akan tetapi perlu ditingkatkan kesesuaiannya dengan materi.

\subsection{Pembahasan}

Ahli media menilai lima aspek yaitu tampilan fisik, gambar, warna, tulisan, dan pemakaian. Diagram penilaian ahli media dapat dilihat pada gambar 3. Aspek tampilan fisik memperoleh nilai rata-rata sebesar $78,13 \%$. Hal ini menunjukkan media ajar lubang hitam dari aspek tampilan fisik cukup layak untuk dikembangkan. Berdasarkan saran dari ahli, bahan yang terbuat dari besi dapat diganti dengan material yang lebih ringan.

Aspek gambar memperoleh nilai rata-rata sebesar 75,00\%. Hal ini menunjukkan media ajar lubang hitam dari aspek gambar cukup layak untuk dikembangkan. Gambar dinilai terlalu berat untuk pengguna, akan lebih baik apabila dibuat karakter yang menarik. Aspek warna memperoleh nilai rata-rata sebesar $81,25 \%$. Hal ini menunjukkan media ajar lubang hitam dari aspek gambar layak untuk dikembangkan. Aspek tulisan memperoleh nilai rata-rata sebesar $75,00 \%$. Hal ini menunjukkan media ajar lubang hitam dari aspek tulisan cukup layak untuk dikembangkan. Font tulisan yang dipakai kurang menarik sehingga perlu dilakukan perbaikan. Aspek pemakaian 
memperoleh nilai rata-rata 75,00\%. Hal ini menunjukkan media ajar lubang hitam dari aspek pemakaian cukup layak untuk dikembangkan. Media yang terbuat dari besi dan ukuran yang besar membuat alat ini sulit digunakan dan tidak praktis untuk dibawa. Material yang lebih ringan dan ukuran yang lebih kecil dapat memudahkan pengguna dalam menggunakan media ini. Berdasarkan penilaian dari dua validator untuk media, rata-rata nilai yang diperoleh adalah sebesar 76,88\%. Dari segi media, media ajar lubang hitam ini masuk kategori cukup layak untuk dikembangkan.

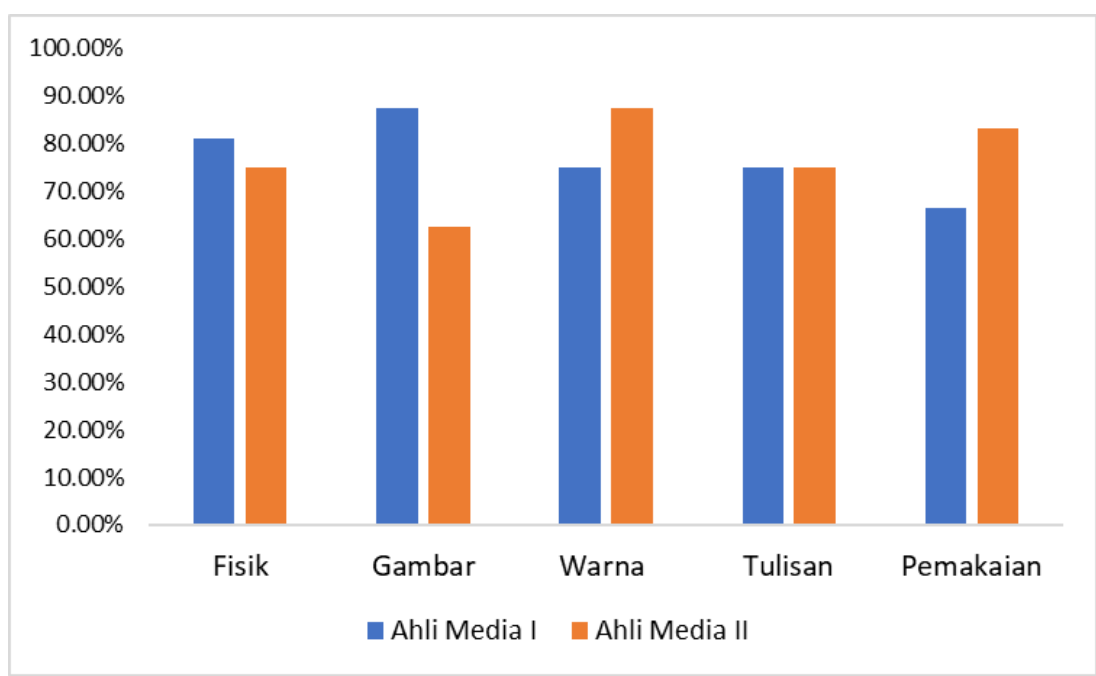

Gambar 3. Diagram penilaian ahli media

Ahli materi menilai dua aspek yaitu kesesuaian materi dan kesesuaian media dengan materi. Diagram penilaian ahli materi dapat dilihat pada gambar 4. Aspek kesesuaian materi memperoleh nilai rata-rata $73,21 \%$. Hal ini menunjukkan media ajar lubang hitam dari aspek kesesuaian materi cukup layak untuk dikembangkan. Materi dinilai terlalu sulit untuk pengguna dengan kategori anak sekolah, sebaiknya materi disesuaikan dengan kurikulum yang ada di sekolah agar sinkron dan bermanfaat. Aspek kesesuaian media terhadap materi memperoleh nilai rata-rata $87,50 \%$. Hal ini menunjukkan media ajar lubang hitam dari aspek kesesuaian media terhadap materi layak untuk dikembangkan. Berdasarkan penilaian dari dua validator untuk materi, rata-rata nilai yang diperoleh adalah sebesar 80,36\%. Dari segi materi, media ajar lubang hitam ini masuk kategori layak untuk dikembangkan.

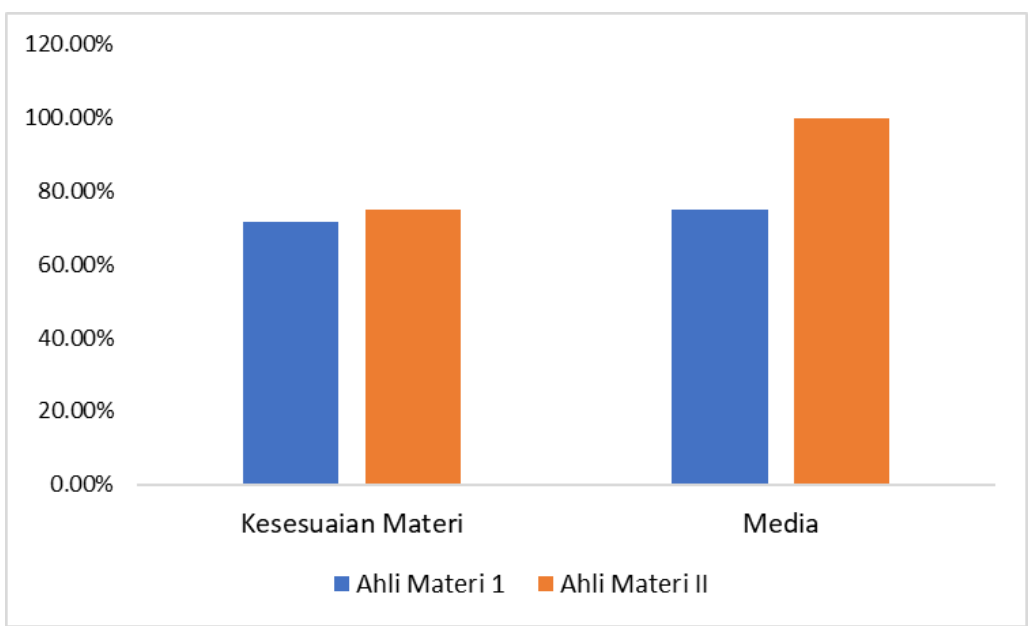

Gambar 4. Diagram penilaian ahli materi

Rata-rata validasi dari ahli media dan ahli materi diperoleh sebesar 78,62\% dengan kategori cukup layak. Dari hasil ini dapat disimpulkan media ajar lubang hitam cukup layak digunakan. Dengan melakukan perbaikan pada beberapa aspek dapat membuat media ini menjadi lebih baik 
lagi. Dengan adanya media lubang hitam tersebut dapat membuat nyata konsep yang abstrak sebagaimana manfaat penggunaan dari media dalam proses pembelajaran. Penggunaan media dalam proses pembelajaran memiliki beberapa manfaat seperti, memberikan suasana yang menyenangkan dalam belajar, memberikan variasi dalam pembelajaran, menghadirkan obyek-obyek yang sukar didapat ke dalam lingkungan belajar, mengatasi keterbatasan ruang, waktu dan daya indera, dan membuat nyata konsep yang abstrak (12). Penelitian ini hanya dibatasi pada penilaian ahli, dan belum diniliai oleh pengguna. Penelitian selanjutnya yang dapat dilakukan adalah menguji media kepada pengguna dan juga mengembangkannya dalam bentuk media digital.

\section{SIMPULAN DAN SARAN}

\subsection{Simpulan}

Berdasarkan penilaian dari dua validator untuk media, rata-rata nilai yang diperoleh adalah sebesar 76,88\%. Media ajar lubang hitam dari segi media masuk kategori cukup layak untuk dikembangkan. Berdasarkan penilaian dari dua validator untuk materi, rata-rata nilai yang diperoleh adalah sebesar 80,36\%. Media ajar lubang hitam dari segi materi masuk kategori layak untuk dikembangkan. Rata-rata validasi dari ahli media dan ahli materi diperoleh sebesar 78,62\% dengan kategori cukup layak. Dengan melakukan perbaikan pada beberapa aspek dapat membuat media ini menjadi lebih baik lagi.

\subsection{Saran}

Penelitian selanjutnya sebaiknya membuat media yang sesuai dengan kategori usia. Juga sebaiknya silakukan pengujian langsung kepada pengguna agar memperoleh hasil yang diharapkan. Penelitian selanjutnya juga dapat mengembangkan media ajar lubang hitam dalam bentuk media digital.

\section{DAFTAR PUSTAKA}

1. Tiandho Y, Triyanta. Transfer Panas Lubang Hitam Schwarzschild. J MIPA. 2014;37(2):130-5.

2. Strathern P. Stephen Hawking dan Lubang Hitam (Black Holes). Surabaya: Ikon Teralitera; 2004.

3. NASA. What Is a Black Hole? [Internet]. https://www.nasa.gov. 2015 [cited 2021 Feb 9]. Available from: https://www.nasa.gov/audience/forstudents/k-4/stories/nasa-knows/what-isa-black-hole-k4.html

4. Yunus FM. Lubang Hitam Akhir dari Ornamen Jagad Raya. J Filsafat. 2003;34(2):103-10.

5. Rohmah KN, Desnita D, Permana AH. Rancangan Buku Pengayaan Pengetahuan "Kajian Fisis Lubang Hitam." Pros Semin Nas Fis. 2016;5:41-4.

6. Sujana N, Supeno H. Desain Prototipe Media Pembelajaran Simulasi Tata Surya pada Pelajaran Astronomi. J Teknol Inf Dan Komun. 2020;7(1):51-7.

7. Puspitasari AD. Penerapan Media Pembelajaran Fisika Menggunakan Modul Cetak dan Modul Elektronik pada Siswa SMA. J Pendidik Fis [Internet]. 2019;7(1):17-25. Available from: http://journal.uin-alauddin.ac.id/indeks.php/PendidikanFisika\%0Ap-ISSN

8. Pane A, Dasopang MD. Belajar dan Pembelajaran. Fitrah. 2017;3(2):333-52.

9. Kallesta KS, Yahya F, Erfan M. Analisis Faktor Penyebab Kesulitan Belajar IPA Fisika pada Materi Bunyi Kelas VIII SMP Negeri 1 Labuhan Badas Tahun Ajaran 2016 / 2017. QUARK J Inov Pembelajaran Fis dan Teknol [Internet]. 2018;1(1):51-7. Available from: http://journal.uin-alauddin.ac.id/indeks.php/PendidikanFisika\%0Ap-ISSN

10. Nurrita T. Pengembangan Media Pembelajaran Untuk Meningkatkan Hasil Belajar Siswa. Misykat. 2018;3(1):171-87.

11. Ramli M. Media dan Teknologi Pembelajaran. Banjarmasin: Antasari Press; 2012.

12. Handhita ET, Akhlis I, Marwoto P. Pengembangan Media Pembelajaran Materi Astronomi Berbasis Visual Novel Ren'Py. Unnes Phys Educ J. 2016;5(2):35-41.

13. Butar-Butar AJR. Urgensi dan Kontribusi Observatorium di Era Modern. J Tarjih. 
2016;13(2):141-54.

14. Qorib M, Zailani, Radiman, Amrizal, Rakhmadi A juli. Peran dan Kontribusi OIF UMSU dalam Pengenalan Ilmu Falak di Sumatera Utara. J Pendidik Islam. 2019;10(2):133-41.

15. Tim OIF UMSU. Profil Singkat Observatorium Ilmu Falak Universitas Muhammadiyah Sumatera Utara. Bandung: Bildung; 2020.

16. Astuti IAD, Sumarni RA, Saraswati DL. Pengembangan Media Pembelajaran Fisika Mobile Learning berbasis Android. J Penelit Pengemb Pendidik Fis. 2017;3(1):57-62. 